NOTES ON SOME OF THE RESULTS OF THE RE-HOUSING OPERATIONS IN LIVERPOOI.**

Br E. W. HOPE, M.D., D.Sc., Medical Officer of Health for Liverpool.

NOTWITHSTANDING the removal of large numbers of insanitary courts and alleys by either the Corporation or by the necessities of increasing commercial enterprise and need for more warehousing, railway or dock accommodation, Liverpool still had a larger proportion of insanitary dwellings built back to back and arranged in narrow courts and alleys than any other town.

The important agencies of commercial enterprise have, since 1864, largely helped in the removal of insanitary property. The needs of railway and warehouse companies, and many other businesses, have led to the removal of from 40 to 50 per cent. of those insanitary dwellings which have disappeared, the balance having been dealt with by the Corporation.

In November of 1883, a special committee, called the Insunitary Property Committee, under the presidency of the late Sir A. B. Forwood, was appointed to deal with this subject, which hitherto had formed part of the duties of the Health Committee.

It appears that at that time something like 2,300 insanitary courts remained, which contained approximately some 15,000 houses.

A forecast made by Sir Arthur Forwood at the time, as to the cost of dealing with the whole of that property, including the cost of land and buildings, was $£ 750,000$; and that to provide accommodation for some two-thirds of those dispossessed, whom it would be necessary to provide for, would be another $£ 660,000$, making a total of $£ 1,410,000$.

The return in rentals, he estimated, would leave a loss to the Corporation of not more than a fraction over $1 d$. in the $f$ on the rates, a loss which, he pointed out, would be more apparent than real, for the gain to the town in health would mean reduced poverty, diminished drunkenness, and better labour.

In 1900 the name of the Insanitary Property Committee was changed to that of Housing Committee, with a view to give greater emphasis to the need to rebuild as well as to pull down, since private enterprise was unable to provide the necessary dwellings in the suitable parts of the city, and the demands upon the ratepayers were increasing.

* Paper read before a meeting of the Incorporated Society of Medical Officers of Health, 13 th March, 1908
Up to 1900 almost all of the insanitary property dealt with by the Corporation had been dealt with under a local Act which had enabled the Corporation to demolish insanitary houses, but left it optional with the owner whether he would sell or retain the site. In view of the fact that the insanitary houses were aggregated together in large blocks, the local Act enabled the Corporation to clear entire areas which, on the purchase of the ground, have formed good sites upon which workmen's dwellings have been erected. The excellent areas known as the Adlington Street and Dryden Street areas were acquired in this way, but latterly, owing to the great aggregations having been dealt with, and remaining insanitary areas being interspersed with property which was not insanitary, the usual procedure under the Housing of the Working Classes Act, has been followed, and operations under the local Act have been very much restricted.

It is under the Housing of the Working Classes Act that the great schemes in the areas known respectively as Hornby Street, Northumberland Street, Mann. Street, and others, have been carried out ; furthermore, the five large schemes at present in progress are all of them proceeding under the Housing of the Working Classes Act. Altogether, ten schemes under the Housing of the Working Classes Act have been wholly carried through, or are now in progress. The Adlington Street, and Dryden Street areas, already alluded to, came into existence through the Liverpool Sanitary Amendment Act of 1864, whilst the Victoria Square dwellings were built under the Artizans' and Labourers' Dwellings Act of 1875. Since 1901, all the re-housing has been accomplished under the Housing of the Working Classes Act.

With regard to the isolated blocks of insanitary houses dealt with, which through their situation could not be included in the scheme, Closing Orders have been the lever of demolition, either of the whole, or part, according to the possibility or otherwise of improving part of the property. It has been found convenient to have recourse also to the Local Act, as the Local Act enables a certain compensation to be paid, and in proceeding with Closing Orders this small compensation has oiled the machinery of progress very considerably, and removed a considerable amount of hostility and opposition which must have resulted in difficulty and delay. 
The question of licensing, and of the sale of drink, bears very definitely upon our subject.

In order to acquire areas for rebuilding under the Housing of the Working Classes Act, the properties existing must be purchased and paid for: The first point to obtrude itself in these poverty-stricken, squalid, and insanitary districts is the large number of licensed premises upon them.

The value of the licensed premises, way three or four in an area, is so great as to very materially swell the entire cost of a schene to the ratepayer. As a consequence of this, the Housing Committee, reluctant to impose these burdens upon the ratepayer, have left the licensed premises, usually comer ones, untouched, to their subsequent great regret; and not only so, but they have even stayed their hands, and refrained from dealing with an insanitary area for a time on account of the immense cost from this circumstance.

It is of course open to discussion how far a sanitary authority is justified in spending money borrowed for purposes under the Housing of the Working Classes Act in buying-out licenses.

But there is yet another financial aspect of the question, viz., the amount wasted by the people in drink, which, if properly spent, would do more towards alleviating the misery and wretchedness with which we are confronted in these districts than anything which charity in all its forms, or even the Corporation of Liverpool, can do.

For example, in the miserable and squalid Hornby Street area there were five public houses, and it was proved that in three of them upwards of $£ 5,000$ per annum was spent in drink, notwithstanding that there were 48 more licensed premises, each doing no doubt as large a trade, within 200 yards of the area.

I am putting these facts to shew that the money will be well spent in extinguishing these licensed premises-- that less waste in drink will leave a better margin for rents, and a less scanty supply of clothes and food for the children.

To return to the dwellings. At the present time the Corporation have in their possession 2,167 dwellings, comprising 5,272 rooms, in addition to scullery, separate w.c., etc. 'The rental of the houses varies from $1 \mathrm{~s}$. $9 \mathrm{~d}$. to 5 s. 6d. per week, in accordance with the amount of accommodation and the situation of the house.
With regard to the financial position of these dwellings, the report for last year shew's a receipt for rents of $\mathfrak{f} 18,325$, and an outlay for upkeep, painting, repairs, wages of attendants, etc., of $\mathbb{E} 8,650$, shewing a net profit for the year of receipts over outlay of about $\mathfrak{E 9}, 675$. This amount goes towards diminishing the debt, paying interest, and sinking fund upon the building. It leaves a deficit of about $\$ 27,873$ a year to make up, and this amount practically represents $2 \mathrm{~d}$. in the $\mathfrak{L}^{2}$ upon the rates.

Since the passing of the 1864 Act there has been expended, including liabilities actually incurred in pending cases approved by the Council for the demolition of insanitary property, and after allowing for sums realised by the sales of surplus land to the 31 st December; 1907, the sum of $\notin 353,657$

For the erection of dwellings and the acquisition of sites under. the Housing of the Working Classes Acts, the sum of $\ldots \quad \notin 524,299$ Making a total of ... $\quad £ 877,956$

of which no less than a sum of $\pm 535,211$ has been expended since 1894 .

To this mast be added the five areas approved of by the City Council on the 6th February last year. Schemes passed the meeting of the Council on that day which deal under the Housing of the Working Classes Act with five more insanitary areas, comprising some 800 slum dwellings, and provide for the entire suitable rebuilding of these areas. The estimated cost is about $£ 275,000$, interest and sinking fund repayable with the sanction of the L.G.B. in eighty years as regards land, sixty years as regards buildings.

There is now an exceedingly important matter to be referred to concerning the tenements. These Corporation dwellings are not let to every applicant. They are reserved exchusively, and very wisely, for those who have been dispossessed by the action of the Corporation, either by the demolition of their houses, by proceedings taken against them on account of breaches of the laws relating to over-crowding in an otherwise sanitary dwelling, or by the closure of an illegal cellar dwelling. 
This policy results in some temporary finmonal loss. At the present time something like eighty houses are empty, awaiting tenants. 'These houses are held in reserve against the next more in the direction of demolition, which is now pentling. Mr. Taylor, the manager, informs me that he would derive approximately $₫ 1,500$ a year more incone from these dwellings if he were allowed to let them to anyone, presumably at their full market ralue, instead of at the nore morlest rentals now asked.

The following statistics relating to the applications for Corporation tenements during 1907 tell their own story, and give the results of investigations made into the circumstances of each applicant for a house :-

Number of applieations received and investigated

Reasons given for making application :-

House stated to be overcrowded

$\begin{array}{cccc}\text { Cellar } & , & , & \text { insanitary... } \\ , & , & , & \text { overcrowded } \\ , & , & , & \text { insanitary... } \\ \text {, } & , & \text { illegal }\end{array}$

About to be dispossessed

$$
\text { Total }
$$

Number of applicants who gave false addresses ...

Number of applications where alleged overcrowding was found on investigation not to exist

$$
\text { ... } \quad \cdots
$$

Number of cases of one family overcrowding house of whom 11 accepted dwellings $\quad \ldots \quad \ldots$

Number of cases of overcrowding cellars of whom 7 accepted dwellings

Number of cases of illegal occupation of cellar of whom 4 accepted $\begin{array}{llllll}\text { dwellings } & \ldots & \ldots & \ldots & \ldots\end{array}$

\section{SUB-LET HOUSES.}

Number of sub-let houses stated to be overcrowded $\quad \ldots \quad$... $\quad \ldots$

Number found overcrowcled on night $\begin{array}{llllll}\text { visit } & \ldots & \ldots & \ldots & \ldots\end{array}$

Number where alleged overcrowding was found abated on night visit ...
Number of convictions for overcrowding ... $\quad \ldots \quad \ldots \quad \ldots \quad \ldots$

Number of applicants from overcrowled sub-let houses who accepted dwellings ... $\quad \ldots \quad \ldots$

The total number of cases of overcrowding in ordinary dwellings, sub-let louses, and cellars, and in the case of illegal occupation of cellars, was 111, in 51 of which the applicants were allowed to rent a Corporation dwelling.

In a considerable number of cases the overcrowding was of recent date, and the offence had evidently been committed with the intention of qualifying for a Corporation house. For instance, in 14 cases the length of tenancy ranged from 1 day to 3 weeks.

In some cases the applicants were found to be drunk at the time of the inquiry. Thirteen cases of drunkenness came under the notice of the inspectors.

The total number of day visits paid with the object of ascertaining the genuineness of the application, during the year, was 575, and 124 night visits were paid, the total number for the year being 699 .

The important point of the rates of sickness and mortality in the new dwellings must be referred to. The returns are most favourable in those dwellings which are most airily situated and most open. They are less favourable, and even disappointing, in dwellings built in the more congested area. This, however, must partly be accounted for by the fact that the occupants and their progenitors have for several generations lived under insanitary surroundings. Their habits and customs are not good, and mend but slowly. Moreover, they are among the most prolific sections of the population, and the rapid increase in families creates difficulties in regard to overcrowding, a circumstance which emphasises the fact that it is impossible to keep them all in the districts where many desire that they should remain; there must be an overflow.

The actual rates of mortality in the old insanitary dwellings averaged about 50 per 1000 per annum. In some blocks they were considerably higher during the few years preceding their demolition, whilst in others these rates were about 45 per 1000 .

The arcompanying tables indicate the statistics for the last two years of all the Corporation dwellings which have been occupied during that period. 
CORPORATION DWELLINGS-1906.

\begin{tabular}{|c|c|c|c|c|c|c|c|}
\hline Dwellings. & $\begin{array}{l}\text { Population } \\
\text { census, } \\
\text { Jaly, } 1007 .\end{array}$ & $\begin{array}{l}\text { No. of birthe } \\
1906 \text {. }\end{array}$ & $\begin{array}{l}\text { Birth rate } \\
\text { per } 1000 \text {. }\end{array}$ & $\begin{array}{c}\text { Xo. of deaths. } \\
190 \% .\end{array}$ & $\begin{array}{l}\text { Death rate } \\
\text { per } 1000 \text {. }\end{array}$ & $\begin{array}{l}\text { No of deaths } \\
\text { below } 1 \text { year. }\end{array}$ & $\begin{array}{l}\text { Infaut death } \\
\text { rate per 100ar } \\
\text { burths. }\end{array}$ \\
\hline St. Martin's Cottages & 428 & 19 & 44 & 11 & 25.7 & 3 & 157 \\
\hline Victoria Sq. and Juvenal Bldgs... & 1190 & 84 & 70 & 34 & 285 & 15 & 178 \\
\hline Gildarts Gardens Group ... & 868 & 41 & 47 & 29 & $33 \cdot 4$ & 13 & 317 \\
\hline Dryden and Rachel Streets, etc. & 647 & 31 & $4 \hat{\imath}$ & 31 & $47 \cdot 9$ & 11 & 354 \\
\hline Kempston Street Cronp & 291 & 19 & 65 & 10) & $: 34: 3$ & 1 & 52 \\
\hline Newsham and Kew streets & 455 & 16 & 35 & 17 & $37 \cdot 3$ & $\stackrel{2}{2}$ & 125 \\
\hline Adlington Street Groul ... & 827 & 32 & 38 & 43 & $51 \cdot 9$ & 11 & 343 \\
\hline Stanlhope Cottages & 243 & 8 & 32 & 7 & $28 \cdot 8$ & 1 & 125 \\
\hline Hornby Street Group $\quad \ldots$ & 599 & 39 & 65 & 17 & $28 \cdot 3$ & 9 & 230 \\
\hline Clivo and Shelley Streets & 300 & 8 & 26 & 14 & $46 \cdot 6$ & 5 & 625 \\
\hline Other small dwellings & 546 & 29 & 53 & 8 & - & 4 & 138 \\
\hline Total Population ... & 6394 & 326 & 51. & 221 & 345 & 75 & 230 \\
\hline
\end{tabular}

CORPORATION DWELLINGS-YEARS 1906 AND 1907.

\begin{tabular}{|c|c|c|c|c|c|c|c|c|}
\hline Dwellings. & & $\begin{array}{c}\text { Population } \\
\text { census, } \\
\text { July, } 1907 .\end{array}$ & & $\begin{array}{l}\text { Average } \\
\text { birtl rate } \\
\text { per 1,000. }\end{array}$ & $\begin{array}{l}\text { No, of deaths, } \\
1906 \text { \& } 1907 .\end{array}$ & $\begin{array}{l}\text { A verage } \\
\text { deatt rate } \\
\text { per } 1,000 .\end{array}$ & $\begin{array}{l}\text { No. of deaths, } \\
\text { below } 1 \text { year, } \\
\text { 1906 \& y 1907. }\end{array}$ & $\begin{array}{l}\text { Average } \\
\text { infant death } \\
\text { rate per } \\
\text { t,000 births. }\end{array}$ \\
\hline St. Martin's Cottages & $\ldots$ & 428 & 55 & 64 & 13 & $15 \cdot 2$ & 3 & 78 \\
\hline Victoria Sq. and JuvenaI Gdns. & . & 1190 & 151 & 63 & 66 & $27: 6$ & 29 & 193 \\
\hline Gildarts Gardens Group ... & & 868 & 105 & 60 & 68 & 385 & 26 & 260 \\
\hline Dryden and Rachel Streets, etc. & & 647 & 96 & 73 & 55 & $37 \cdot \tilde{0}$ & 21 & 253 \\
\hline Kempston Street Group ... & . & 291 & 37 & 63 & 27 & $46 \cdot 2$ & 3 & 81 \\
\hline Newsham and Kew Streets & $\ldots$ & 455 & 44 & 48 & 30 & 32.9 & 9 & 187 \\
\hline Adlington Street Group $\ldots$ & \{ & $\begin{array}{r}827(1906) \\
1016(1907)\end{array}$ & \} & 45 & 74 & $41-2$ & 21 & 265 \\
\hline Stanhope Cottages & $\ldots$ & 243 & 16 & 32 & 8 & $\ldots$ & 1 & 63 \\
\hline Hormby Street Group & \{ & $\begin{array}{r}599(1906) \\
1374(1907)\end{array}$ & 133 & 66 & 63 & $30 \cdot 8$ & 22 & 184 \\
\hline Clive and shelley Streets & $\ldots$ & 300 & 27 & 45 & 24 & $39 \cdot 9$ & 8 & 391 \\
\hline Ulper Manu Street & & $297(1907)$ & $\begin{array}{c}18 \\
\text { (1 year) }\end{array}$ & $\begin{array}{c}60 \\
\text { (1 yeall) }\end{array}$ & $\begin{array}{c}7 \\
\text { (1 year) }\end{array}$ & $\begin{array}{c}235 \\
\text { (1 year) }\end{array}$ & 1 & $\begin{array}{c}55 \\
\text { (1 year) }\end{array}$ \\
\hline Other small dwellings & \{ & $\begin{array}{l}546(1906) \\
359(1907)\end{array}$ & 48 & 52 & 18 & 212 & 10 & 226 \\
\hline 'Total Population ... & \{ & $6394(1906)$ & \} 815 & 58 & 453 & $32 \cdot 7$ & 154 & 195 \\
\hline
\end{tabular}


CORPORATION DWELLINGS 1907.

\begin{tabular}{|c|c|c|c|c|c|c|c|}
\hline Dwellings. & $\begin{array}{l}\text { Population } \\
\text { census, } \\
\text { Inly, } 1907 .\end{array}$ & $\begin{array}{l}\text { No. of birtlss, } \\
1907 \text {. }\end{array}$ & $\begin{array}{l}\text { Birth rate } \\
\text { per' } 1,000 \text {. }\end{array}$ & $\begin{array}{c}\text { No.of } \\
\text { deaths, } 190 \pi .\end{array}$ & $\begin{array}{l}\text { Death rate } \\
\text { per } 1,1000 .\end{array}$ & $\begin{array}{l}\text { No. of deaths } \\
\text { below } \\
1 \text { year. }\end{array}$ & $\begin{array}{l}\text { Intaut death } \\
\text { rate per } 1,000 \\
\text { births. }\end{array}$ \\
\hline St. Martin's Cottag'es & 428 & 36 & 84 & 2 & - & - & - \\
\hline Victoria Sq. and Juvenal Bldgs. ... & 1190 & 67 & 56 & 32 & $26 \cdot 8$ & 14 & 209 \\
\hline Gildarts Gardens Gromb ... & 868 & 64 & 73 & 33 & $43 \cdot 7$ & 13 & 203 \\
\hline Dryden and Rachel streets, etc. ... & 647 & 65 & 100 & 24 & $37 \cdot 0$ & 10 & 153 \\
\hline Kempston Street Group ... & 291 & 18 & 61 & 17 & $58 \cdot 1$ & 2 & 111 \\
\hline Newsham and Kew Streets & 455 & 28 & 61 & 13 & 285 & 7 & 250 \\
\hline Adlington Street Group $\ldots$ & 1016 & 53 & 52 & 31 & $30 \cdot \overline{5}$ & 10 & 188 \\
\hline Stanhope Cottages & 243 & 8 & 32 & 1 & - & $\ldots$ & - \\
\hline Hornby Street Grony) $\quad \ldots$ & 1374 & 94 & 68 & 46 & $33 \cdot 4$ & 13 & 138 \\
\hline Clive and Shelley Streets & 300 & 19 & 63 & 10) & $33 \cdot 3$ & 3 & 158 \\
\hline Upper Mann Street & 297 & 18 & 60 & 7 & 235 & 1 & 55 \\
\hline $\begin{array}{l}\text { Other small dwellings - Arley, } \\
\text { Mill, Toxteth and EIdon Streets }\end{array}$ & 359 & 19 & 52 & 10 & $27 \cdot 8$ & 6 & 315 \\
\hline Total Population ... & 7468 & 489 & 65 & 232 & $31 \cdot 0$ & 79 & 161 \\
\hline
\end{tabular}

It is quite true that the populations are not large, nor is the period of two years a long one, yet the returns tell an important story. Clearly there is still something wanting, and that something is an improvement in the personal factor, an improvement in the habits, and in the care and attention bestowed upon infants and young children.

A close inquiry reveals the existence of many families living under very adverse conditions, but, owing to the intelligence and sobriety of the parents (and the two always go together), the whole of the large family has been successfully reared.

There is on the other hand the opposite extreme, where lack of intelligence, thriftlessness, dirty habits, and frequent drinking bouts have resulted in neglect of the household and the loss of life of the infants, but the improved environment has unquestionably led to general improvement, and continuerl, kindly, and tactful supervision will effect a great deal more.

\section{DISCUSSION.}

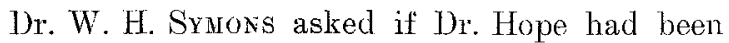
able to overcome the difficulty in regard to storing of food. The difficulty they had had to contend with in Bath was to provide a food store free from the emanations of the room.
Dr. G. F. MoClear commented apon the admirable photographs submitted by Dr. Hope in connection with his paper. He was of opinion that bad sanitary conditions should be photographed and put on record, so that future historians should be able to see what had been achieved in the past.

Dr. P. CaLdwell Smrth said that in London'as a whole they desired to know definitely whether the mortality in the large dwellings was greater: than in the cottage dwellings. In his district, the London County Council had only erected the cottage type of dwelling, with large open spaces. It would be most interesting to have some statistics in regard to the birth and death rates in these different classes of property.

Dr. War. Burcer said they had before them a public health experiment on a gigantic scale, at a tremendous cost, with most satisfactory results. They had an example of a population housed in insanitary conditions, and the same population housed in sanitary conditions. A death rate of 45 to 50 per thousand reduced to 30 per thousand was ample justification for the steps that had been taken. With a death rate of 30 per thousand in the model dwellings of Liverpool, there was still a large margin for improvement, and, in his opinion, that was to be brought about by dealing with the habits of the people themselves. Referring to the rentals charged by the Liverpool Corporation, they appeared to him to be very low.

Dr. H. Beals Coluins asked whether the Society possessed a copy of Dr. Hope's book, prepared for 
one of the recent congresses, and if not, ventured to suggest that Dr. Hope should present a copy for the library of the Societs.

Dr. F. F. Frevante tousted that Dr. Hope would eventually be able to give the statistics for a period of years. He was also of opinion that a further improvement in the death rate was to be looked for by helping to improve the habits of the people by erincation. This should be done during the school-time of the individual.

Dr. T. D. MCCRriner said that a considerable amount of good work had been done in Birmingham at a very modest cost to the Corporation, but with regard to rentals, the Corporation had no real control over the landlords. Where landlords had been compelled to put dwellings into sanitary repair, it had resulted in raising rents to a certain extent.

Dr. Herbert . Joxes considered that the Society was inclebted to Dr. Hope for pointing out to the sanitary authorities of this country that it was quite possible to work the provisions of the Housing of the Working Classes Act. They had the greatest difficulty to persuade owners in mural districts that insanitary cottages were nnfit for habitation. He was usually met with the remark that such cottages had done for generations, and were quite gool enough now. Referring to the very high birth rates mentioned by Dr. Hope, he thought that on examination they were not really so high as they artnally appeared. It seemed to him that it was very unlikely there would be many old people in the dwellings. No doubt most of the old people would go the workhouse. If I)r. Hope were to work out his birth rate in the same way as the Registrar-General had been doing of late, he wonld find that it was not so high as it appeared.

Dr. Crookshank asked if the rate was corrected, and if Dr. Hope could give any information in regard to the prevalence of infectious disease in these dwellings.

Dr. H. Meredith Rrohards (chairman) considered that the Society should congratulate the Liverpool Corporation on the courage and success with which the experiment had heen carried out. As to the birth rate, it was essential that it should be corrected, not only in regard to institutions, but. also in regard to age and sex. It was also a question whether the old people should always be referred to the slum district from which they came. As to the Liverpool slums, he was personally indebted to them for the only outbreak of typhus fever he had seen. He moved that a hearty vote of thanks be accorded to Dr. Hope for his excellent paper. This was carried by acclamation.

Dr. Hope, in reply to the point raised by Dr. Symons, said that the food stores which had been provided had not always been as satisfactory as they wished, but as they went on, so they inproved in the details of these dwellings. With reforence to the remarks made in regard to the vital statistics, it was a very difficult thing to gruge the exact position in these dwellings. His personal impression was that the birth rate was really high. He quite agreed with Dr. MeCleary as to the importance of photography in their work. Unless they could chronicle in some way what the condition of things was before improvement was made, they had nothing to gange the improvement. by. With regard to the personal factor, he looked ripon it as a most important point, and was endearouring to make an investigation into that side of the question. As to the deaths, almost all those in the ponrest parts of Liverpool take place in public institutions. He had made a comparison with Leeds and Manchester, and the same story of poverty was revealed there. In Liverpool they followed the usual practire of retming the deaths from the districts whence they came. There is not a large amount of infertions disease in Liverpool; it had, in fact, very much diminished, owing to the excellent hospital equipment provided for the city. He should be pleased to provide the library with a cops of the rolume referred to by Dr. Beale Collins, and thanked the meeting for the kind manner in which they had received his paper.

\section{SIR HENRY IITTLEJOHN'S RESIG- NATION.}

A.L who are engaged in public health work A will regret to learn that Sir. Henry Littlejohn has resigned his post as Medical Officer of Health of Edinburgh, a post he has held for the last forty-six years. Sir Henry took his doctor's degree as long ago as 1847, and his period of office las extended considerably beyond the fatal sixty-fith year that marks the conclusion of most official careers. It would be superfluous to dilate upon the great services Sir Henry has rendered, both as administrator and teacher, to the cause of public health progress during his long period of office. There are few reforms that have not owed much to his efforts. As a public health teacher Sir Henry held a unique position. His pupils have gone forth into all lands, and many a distinguished health offices: has learnt his first lessons in public health from those racy Edinburgh lectures, as full of wit and humour as of shrewd common sense and sound epidemiological teaching. Although Sir Henry's official life is over we trust he will still continue to attend the ammual Congresses of public health workers, and that his wise advice and cheery encouragement will long be heard by those who are still actively grappling with the problems of the prevention of disense.

A 'I'Ubencurous Cow.-The first prosecution at Leeds under the Milk Provisions of the Leeds Corporation (General Powers) Act, 1901, came hefore the Leeds Police Court on March 10, 1908, when Walter Bailey, a farmer of Kirkstall, was fined $\mathfrak{E} 1$ and costs for neglecting to give written notice to the Medical Officer of Health that he had in his dairy a cow affected with tuberculosis of the udder. 